\title{
EFEKTIVITAS FUNGSI LEMBAGA ADAT KEUJREUN BLANG DALAM PENGELOLAAN AIR IRIGASI DI KECAMATAN KUTA COT GLIE KABUPATEN ACEH BESAR
}

\author{
(The Effectiveness Of The Traditional Keujreun Blang Institution Function In The \\ Management Of Irrigation Water In The Kuta Cot Glie Sub-District, Aceh Besar District)
}

\author{
Eka Maulida ${ }^{1}$, Sofyan $^{1}$, T. Makmur ${ }^{1 *}$ \\ ${ }^{1}$ Program Studi Agribisnis, Fakultas Pertanian, Universitas Syiah Kuala
}

\begin{abstract}
Abstrak. Keujreun blang merupakan lembaga yang mengatur kegiatan di bidang usaha persawahan yang mempunyai tugas menentukan dan mengkoordinasikan tata cara turun kesawah, mengatur pembagian air kesawah petani, membantu pemerintah dalam bidang pertanian, mengkoordinasikan khanduri blang dan upacara lain yang berkaitan dengan adat dalam usaha pertanian sawah, memberi teguran atau sanksi kepada petani yang melanggar aturan-aturan adat meugo atau tidak melaksanakan kewajiban lain dalam sistem pelaksanaan pertanian sawah secara adat serta menyelesaikan sengketa antar petani yang berkaitan dengan pelaksanaan usaha pertanian. Kecamatan Kuta Cot Glie Kabupaten Aceh Besar merupakan salah satu daerah yang telah memunculkan suatu pemikiran untuk menguatkan kembali peranan dan keberadaaan keujreun blang sebagai salah satu lembaga yang ada di Aceh sejak tahun 1817. Penelitian ini bertujuan untuk mengetahui tingkat efektivitas fungsi lembaga adat keujreun blang dalam pengelolaan air irigasi. Penelitian ini dilaksanakan di Kecamatan Kuta Cot Glie Kabupaten Aceh Besar. Objek dari penelitian ini adalah petani padi sawah yang berada di daerah layanan irigasi yang dikelola keujreun blang di Kecamatan Kuta Cot Glie Kabupaten Aceh Besar. Pengambilan sampel menggunakan teknik Simple Random sampling. Metode analisis data yang digunakan pada penelitian ini adalah teknik analisis deskriptif. Hasil penelitian menunjukkan bahwa pelaksanaan fungsi lembaga adat keujreun blang dalam pengelolaan air irigasi dilihat dari tingkat pelaksanaan pengawasan adat blang, pengawasan ketersediaan air, pengawasan saluran dan penggunaan air, penegakan adat blang, penyelesaian sengketa, dan pemberian teguran dan sanksi dinilai efektif yaitu sebesar 94,7 persen.
\end{abstract}

Kata kunci : Efektivitas, Irigasi, Keujreun Blang.

Abstract. Keujreun blang is an institution that regulates activities in the field of rice fields that have duties to determine and coordinate procedures for descending down, regulate the distribution of water to farmers, assist the government in the field of agriculture, coordinate khanduri blang and other ceremonies related to adat in paddy farming, give reprimands or sanctions to farmers who violate meugo customary rules or not carry out other obligations in the customary paddy farming system and resolve disputes between farmers related to the implementation of agricultural business. Kuta Cot Glie Aceh Besar is one of the areas that has raised a thought to reinforce the role and existence of keujreun blang as one of the existing institutions in Aceh since 1817. This research aims to know the effectiveness of the functioning of the institutions of the indigenous keujreun blang in the management of irrigation water. This research was carried out at Kuta Cot Glie Aceh Besar District. The object of this research is the rice farmers who were in the area of irrigation service managed keujreun blang in Kuta Cot Glie Aceh Besar District. Sampling techniques using Simple Random sampling. Data analysis method used in this research is descriptive analysis techniques. The results showed that the implementation of the custom institution function keujreun blang in irrigation water management as seen from the level of implementation of the customs surveillance, monitoring of water availability blang, surveillance channels and water usage, customs enforcement blang, dispute resolution, and the granting of reprimand and sanctions assessed effectively i.e. of 94.7 percent.

Key words: effectiveness, irrigation, Keujreun Blang.

*Corresponding author: tmakmur.agric@unsyiah.ac.id 


\section{PENDAHULUAN}

Sistem irigasi merupakan suatu kesatuan yang tersusun dari berbagai komponen, menyangkut upaya penyediaan, pembagian, pengelolaan dan pengaturan air untuk meningkatkan produksi di bidang pertanian (Jannata et al., 2015). Dalam memenuhi kebutuhan air untuk berbagai keperluan usaha tani, maka air irigasi harus diberikan dalam jumlah, waktu, dan mutu yang tepat, jika tidak maka tanaman akan terganggu pertumbuhannya yang pada akhirnya akan mempengaruhi hasil produksi pertanian (Sahrirudin et al., 2014).

Ketersediaan air yang cenderung menurun dibandingkan kebutuhan air yang meningkat untuk sektor pertanian dan non pertanian menyebabkan adanya persaingan untuk mendapat sumberdaya air. Pemerintah desa berusaha meningkatkan jaringan irigasi yang berfungsi dengan baik sehingga dapat meningkatkan produksi pangan (Hakim, 2017).

Aceh adalah daerah provinsi yang merupakan kesatuan masyarakat hukum dengan adat istiadat yang bersifat istimewa dan diberi kewenangan khusus untuk mengatur dan mengurus sendiri urusan pemerintahan dan kepentingan masyarakat setempat sesuai dengan peraturan perundang-undangan Negara kesatuan Republik Indonesia tahun 1945. Dalam bidang pertanian atau persawahan, masyarakat Aceh mempunyai suatu lembaga adat yang di sebut sebagai keujreun blang. Keujreun blang merupakan lembaga yang mengatur kegiatan di bidang usaha persawahan yang mempunyai tugas menentukan dan mengkoordinasikan tata cara turun kesawah, mengatur pembagian air kesawah petani, membantu pemerintah dalam bidang pertanian, mengkoordinasikan khanduri blang dan upacara lain yang berkaitan dengan adat dalam usaha pertanian sawah, memberi teguran atau sanksi kepada petani yang melanggar aturan-aturan adat meugo atau tidak melaksanakan kewajiban lain dalam sistem pelaksanaan pertanian sawah secara adat serta menyelesaikan sengketa antar petani yang berkaitan dengan pelaksanaan usaha pertanian.

Dalam pengelolaan air irigasi, keujreun blang mempunyai beberapa fungsi, diantaranya melakukan koordinasi dalam pembagian air antar wilayah, pengawasan saluran, pengawasan ketersediaan air, pengawasan penggunaan air, pengawasan adat blang, pelaksanaan dan penegakan adat blang, serta penyelesaian sengketa dalam pemanfaatan air. Masalah air irigasi merupakan hal yang sangat penting dibidang pertanian, sehingga petani sangat rentan jika terjadi kekurangan distribusi air. Dengan menipisnya distribusi air maka akan mengurangi debit air yang masuk ke petak sawah petani. Sehingga tidak jarang akan memunculkan konflik atau persaingan antar petani pada saat musim kemarau, hal tersebut disebabkan oleh faktor kepentingan masing-masing serta lemahnya penerapan sanksi yang telah ditetapkan.

Kecamatan Kuta Cot Glie Kabupaten Aceh Besar merupakan salah satu daerah yang telah memunculkan suatu pemikiran untuk menguatkan kembali peranan dan keberadaaan keujreun blang sebagai salah satu lembaga yang ada di Aceh sejak tahun 1817. Lembaga keujreun blang merupakan lembaga yang bersifat sosial dengan maksud mendapatkan hasil guna pengelolaan air irigasi, dan untuk meningkatkan kesejahteraan para anggotanya. Di Kecamatan Kuta Cot Glie lembaga tersebut telah didirikan sejak tanggal 19 Desember 1995 namun diaktifkan kembali pada tahun 2007. Pembagian irigasi yang digunakan adalah jaringan irigasi teknis dimana saluran pembawa dan saluran pembuang sudah terpisah. Keujreun blang dibentuk dengan bertujuan mendayagunakan potensi air irigasi yang tersedia di Desa untuk kesejahteraan masyarakat pada umumnya dan petani pada khususnya. Adapun tujuan dari penelitian ini adalah mengetahui tingkat efektitivitas fungsi lembaga adat keujreun blang dalam pengelolaan air irigasi di Kecamatan Kuta Cot Glie Kabupaten Aceh Besar. 


\section{METODE PENELITIAN}

Penelitian ini dilakukan di Kecamatan Kuta Cot Glie Kabupaten Aceh Besar. Penentuan lokasi penelitian dilakukan secara sengaja dengan pertimbangan adanya masyarakat yang bermata pencaharian sebagai petani padi sawah, ketersediaan sarana dan keberadaan lembaga keujreun blang. Objek dari penelitian ini adalah petani padi sawah yang berada di daerah layanan irigasi yang dikelola keujreun blang di Kecamatan Kuta Cot Glie Kabupaten Aceh Besar. Ruang lingkup dari penelitian ini terbatas pada efektivitas fungsi lembaga adat keujreun blang dalam pengelolaan air irigasi di Kecamatan Kuta Cot Glie Kabupaten Aceh Besar.

\section{Populasi, Metode dan Teknik Pengumpulan Data}

Populasi dalam penelitian ini adalah seluruh petani padi sawah yang menjadi anggota dalam lembaga adat keujreun blang, yaitu Blang Harapan yang terdiri dari 4 desa yaitu Desa Lampakuk, Desa Banda Safa, Desa Lamthui dan Desa Lambeugak. Sampel yang digunakan dalam penelitian ini adalah 38 orang dari 381 petani. Metode penelitian yang digunakan pada penelitian ini ialah wawancara langsung dengan menggunakan kuesioner kepada responden terpilih. Adapun teknik pengambilan sampel yang digunakan adalah Simple Random Sampling.

\section{Metode Analisis}

Seluruh data yang diperoleh dalam penelitian selanjutnya ditabulasikan dan di analisis melalui pendekatan kualitatif. Analisis statistik deskriptif dilakukan untuk mendeskripsikan variabel penelitian melalui tahapan: a) penyajian data variabel melalui metode tabulasi, b) penentuan kecenderungan nilai responden untuk masing-masing variabel yang dikelompokkan menjadi tiga kelas yaitu tinggi, sedang, dan rendah. Sebelum diolah, jawaban responden terhadap pertanyaan yang ada terlebih dahulu diberikan pembobotan. skala dan skor jawaban responden diukur dengan menggunakan Skala Likert.

\section{Gambaran Umum Lokasi Penelitian}

\section{HASIL DAN PEMBAHASAN}

Lokasi penelitian dilakukan di Kecamatan Kuta Cot Glie yang berada di Kabupaten Aceh Besar. Secara geografis Kabupaten Aceh Besar terletak pada garis $5,05^{\circ}-5,75^{\circ}$ Lintang Utara dan $94,99^{\circ}-95,93^{\circ}$ Bujur Timur. Sebelah Utara berbatasan dengan Selat Malaka dan Kota Banda Aceh, sebelah Selatan berbatasan dengan Kabupaten Aceh Jaya, sebelah Timur berbatasan dengan Kabupaten Pidie dan sebelah Barat berbatasan dengan Samudera Hindia. Kabupaten Aceh Besar memliki luas wilayah seluas 290.350,75 Ha. Secara administratif Kabupaten Aceh Besar memiliki 23 Kecamatan dan 604 Desa.

\section{Karakteristik Petani}

Karakteristik petani adalah ciri-ciri atau sifat yang dimiliki oleh petani yang dihasilkan melalui pola pikir, pola sikap dan pola tindakan terhadap lingkungannya. Karakteristik petani mempengaruhi petani dalam menjalankan usahatani serta menentukan kemampuan petani dalam mengalokasikan sumber daya yang dimiliki. Karakteristik petani dalam penelitian ini terdiri dari umur, pendidikan, dan luas lahan.

\section{Umur}

Tabel 1. Karakteristik Petani Berdasarkan Umur

\begin{tabular}{llll}
\hline No. & Umur & Jumlah (Orang) & Persentase (\%) \\
\hline 1 & 25-38 Tahun & 17 & 44,7 \\
2 & 39-48 Tahun & 13 & 34,2 \\
3 & 49-65 Tahun & 8 & 21,1 \\
\hline
\end{tabular}

Sumber: Data Primer (diolah), 2018 
Berdasarkan Tabel 1 terlihat bahwa frekuensi umur terbanyak petani pada daerah penelitian adalah umur 25 sampai 38 tahun yang berjumlah 17 orang dengan persentase 44,7 $\%$. Sementara petani dengan frekuensi umur paling sedikit ialah berumur 49 sampai 65 tahun yang berjumlah 8 orang dengan persentase $21,1 \%$. Hal ini menunjukkan bahwa sebagian besar umur petani di daerah penelitian digolongkan kedalam usia kerja produktif yang masih dalam tingkat partisipasi kerja aktif.

\section{Pendidikan}

Tabel 2. Karakteristik Petani Berdasarkan Pendidikan

\begin{tabular}{llll}
\hline No. & Pendidikan & Jumlah (Orang) & Persentase (\%) \\
\hline 1 & Tidak Sekolah & 1 & 2,6 \\
2 & SD & 9 & 23,7 \\
3 & SMP & 8 & 21,1 \\
4 & SMA & 17 & 44,7 \\
5 & Perguruan Tinggi & 3 & 7,9 \\
\hline
\end{tabular}

Berdasarkan Tabel 2 dapat dilihat bahwa tingkat pendidikan terakhir petani responden terbanyak ialah pada jenjang Sekolah Menengah Atas (SMA) yang berjumlah sebanyak 17 orang dengan persentase sebesar 44,7 persen. Sedangkan tingkat pendidikan petani paling rendah yaitu Sekolah Dasar (SD) yang berjumlah sebanyak 9 orang dengan persentase sebesar 23,7 persen dan petani yang tidak bersekolah berjumlah 1 orang dengan persentase sebesar 2,6 persen.

\section{Luas Lahan}

Tabel 3. Karakteristik Responden Berdasarkan Luas lahan

\begin{tabular}{llll}
\hline No. & Luas Lahan & Jumlah (Orang) & Persentase (\%) \\
\hline 1 & $<0,25 \mathrm{Ha}$ & 27 & 71,1 \\
2 & $0,25-0,5 \mathrm{Ha}$ & 8 & 21,1 \\
$\mathbf{3}$ & $>0,5 \mathrm{Ha}$ & 3 & 7,8 \\
\hline
\end{tabular}

Sumber: Data Primer (diolah), 2018

Berdasarkan Tabel 3 diatas dapat dilihat bahwa sebagian besar petani yang menjadi responden memiliki ukuran lahan yang kecil. Jika dilihat dari tabel diatas petani yang memiliki luas lahan kurang dari 0,25 hektar sebanyak 27 orang dengan persentase sebesar 71,1 persen. Petani yang memiliki luas lahan 0,25 hektar sampai 0,5 hektar sebanyak 8 orang dengan persentase sebesar 21,1 persen. Sedangkan petani yang memiliki luas lahan lebih dari 0,5 hektar berjumlah 3 orang dengan persentase 7,8 persen.

\section{Pelaksanaan Fungsi Lembaga Adat Keujreun Blang dalam Pengelolaan Air}

Efektivitas adalah suatu ukuran yang menyatakan seberapa jauh kemampuan melaksanakan tugas dan fungsi yang telah ditetapkan sebelumnya dalam suatu organisasi. Dalam hal ini yang dilihat efektivitasnya adalah fungsi lembaga adat Keujreun Blang dalam pengelolaan air irigasi di Kecamatan Kuta Cot Glie Kabupaten Aceh Besar. Pada penelitian ini hal-hal yang diukur yang dapat mempengaruhi efektivitas terdiri dari pelaksanaan pengawasan adat blang, pengawasan ketersediaan air, pengawasan saluran dan penggunaan air, penegakan adat blang, penyelesaian sengketa dan pemberian teguran dan sanksi. 


\section{Pengawasan Adat Blang}

Tabel 4. Distribusi Tingkat Pelaksanaaan Pengawasan Adat Blang

\begin{tabular}{|c|c|c|c|c|c|c|c|}
\hline \multirow{3}{*}{ No } & \multirow{3}{*}{ Indikator } & \multicolumn{6}{|c|}{ Kategori Skor } \\
\hline & & \multicolumn{2}{|l|}{ Setuju } & \multicolumn{2}{|c|}{ Kurang Setuju } & \multicolumn{2}{|c|}{ Tidak setuju } \\
\hline & & Frekuensi & $\%$ & Frekuensi & $\%$ & Frekuensi & $\%$ \\
\hline 1 & $\begin{array}{l}\text { Pemberian peringatan } \\
\text { terhadap pelanggaran } \\
\text { tata tanam }\end{array}$ & 38 & 100 & 0 & 0 & 0 & 0 \\
\hline 2 & $\begin{array}{l}\text { Pelaksanaan kheunduri } \\
\text { blang }\end{array}$ & 38 & 100 & 0 & 0 & 0 & 0 \\
\hline 3 & $\begin{array}{l}\text { Pelaksanaan gotong } \\
\text { royong }\end{array}$ & 38 & 100 & 0 & 0 & 0 & 0 \\
\hline
\end{tabular}

Berdasarkan Tabel 4 diatas dapat diketahui bahwa pengurus keujreun blang selalu memberikan peringatan terhadap anggota yang melanggar tatan tanam yang telah ditetapkan yaitu dengan persentase sebesar 100 persen. Kemudian untuk pelaksanaan kheunduri blang dan pelaksanaan gotong royong juga sebesar 100 persen. Hal ini menunjukkan bahwa keujreun blang selalu mengkoordinir para anggota untuk melaksanakan kheunduri blang pada setiap musim tanam, begitupun mengenai pelaksanaan gotong royong yang rutin diadakan pada setiap awal musim tanam. Untuk jadwal pelaksanaan kheunduri blang dan gotong royong telah ditetapkan pada saat dilakukan duek pakat sebelumnya.

Tabel 5. Rata-Rata Tingkat Pelaksanaan Pengawasan Adat Blang

\begin{tabular}{clccc}
\hline No & \multicolumn{1}{c}{ Indikator } & Skor & Kategori \\
\hline $\mathbf{1}$ & Pemberian peringatan & terhadap & 3 & Setuju \\
& pelanggaran tata tanam & & \\
$\mathbf{2}$ & Pelaksanaan kheunduri blang & 3 & Setuju \\
$\mathbf{3}$ & Pelaksanaan gotong royong & 3 & Setuju \\
& Rata-rata & $\mathbf{3}$ & Setuju \\
\hline
\end{tabular}

Sumber: Data Primer (diolah), 2018

Berdasarkan Tabel 5 diatas menunjukkan bahwa tingkat pelaksanaan pengawasan adat blang sudah sangat baik yaitu sebesar 3 untuk rata-rata skor ke tiga indikator. Rata-rata skor dari kriteria indikator pemberian peringatan terhadap pelanggaran tata tanam dengan nilai 3 , ini memperlihatkan bahwa pengurus keujreun blang memberikan peringatan terhadap anggota yang melanggar tata tanam. Rata-rata skor dari kriteria indikator pelaksanaan kheunduri blang dengan nilai 3 menunjukkan bahwa kegiatan kheunduri blang selalu diadakan setiap musim tanam. Kheunduri blang merupakan tradisi adat Aceh yang dilakukan masyarakat pada setiap gampong secara turun temurun. Tujuan diadakannya kheunduri blang adalah sebagai ungkapan rasa cukur terhadap hasil panen yang diberikan oleh Allah SWT. Dalam kegiatan ini ada pembacaan doa dan zikir dengan tujuan untuk memohon kepada Allah SWT agar diberikan rezeki serta padi yang ditanami terbebas dari hama dan penyakit. Rata-rata skor dari kriteria indikator pelaksanaan gotong royong dengan nilai 3 menunjukkan bahwa kegiatan gotong royong selalu dilaksanakan pada setiap awal musim tanam. Gotong royong dilakukan dengan tujuan untuk membersihkan saluran irigasi secara bersama-sama sehingga air dapat mengalir dengan lancar. Gotong royong ini dilakukan oleh keujreun blang bersama-sama dengan para anggota, namun jika ada anggota yang tidak hadir maka anggota tersebut harus membayar uang kepada pengurus keujreun blang. 


\section{Pengawasan Ketersediaan Air}

Tabel 6. Distribusi Tingkat Pelaksanaan Pengawasan Ketersediaan Air

\begin{tabular}{|c|c|c|c|c|c|c|c|}
\hline \multirow{3}{*}{ No } & \multirow{3}{*}{ Indikator } & \multicolumn{6}{|c|}{ Kategori skor } \\
\hline & & \multicolumn{2}{|c|}{ Setuju } & \multicolumn{2}{|c|}{ Kurang Setuju } & \multicolumn{2}{|c|}{ Tidak Setuju } \\
\hline & & Frekuensi & $\%$ & Frekuensi & $\%$ & Frekuensi & $\%$ \\
\hline 1 & $\begin{array}{l}\text { Ketersediaan air pada } \\
\text { awal musim tanam }\end{array}$ & 23 & 60,5 & 13 & 34,2 & 2 & 5,3 \\
\hline 2 & $\begin{array}{l}\text { Ketersediaan air sesuai } \\
\text { jadwal yang } \\
\text { ditentukan }\end{array}$ & 25 & 65,8 & 9 & 23,7 & 4 & 10,5 \\
\hline 3 & $\begin{array}{l}\text { Tidak pernah terjadi } \\
\text { kekurangan air }\end{array}$ & 5 & 13,1 & 31 & 81,6 & 2 & 5,3 \\
\hline
\end{tabular}

Berdasarkan Tabel 6 diatas dapat dilihat bahwa tingkat ketersediaan air pada awal musim tanam yaitu sebesar 60,5 persen, ketersediaan air sesuai jadwal yang ditentukan sebesar 65,8 persen sedangkan untuk indikator tidak pernah terjadi kekurangan air hanya sebesar 5 persen. Hal ini berdasarkan jawaban responden melalui pertanyaan yang diajukan peneliti secara langsung.

Tabel 7. Rata-Rata Tngkat Pelaksanaan Pengawasan Ketersediaan Air

\begin{tabular}{|c|c|c|c|}
\hline No & Indikator & Skor & Kategori \\
\hline 1 & $\begin{array}{l}\text { Ketersediaan air pada awal musim } \\
\text { tanam }\end{array}$ & 2,55 & Setuju \\
\hline 2 & $\begin{array}{l}\text { Ketersediaan air sesuai jadwal yang } \\
\text { ditentukan }\end{array}$ & 2,55 & Setuju \\
\hline 3 & $\begin{array}{l}\text { Tidak pernah terjadi kekurangan air } \\
\text { Rata-rata }\end{array}$ & $\begin{array}{l}2,08 \\
\mathbf{2 , 3 9}\end{array}$ & $\begin{array}{l}\text { Kurang Setuju } \\
\text { Setuju }\end{array}$ \\
\hline
\end{tabular}
Sumber: Data Primer (diolah), 2018

Berdasarkan Tabel 7 diatas dapat diketahui bahwa tingkat pelaksanaan pengawasan ketersediaan air dari ketiga indikator tergolong sudah baik dengan nilai rata-rata skor 2,39. Hal ini memperlihatkan bahwa untuk pengawasan ketersediaan air pada awal musim tanam dan ketersediaan air sesuai jadwal yang telah ditentukan yang dilakukan oleh keujreun blang dapat dikatakan sudah baik dengan nilai rata-rata skor sebesar 2,55. Namun, untuk indikator tidak pernah terjadi kekurangan air dapat dikatakan masih belum baik dengan nilai rata-rata skor sebesar 2,08. Artinya, dalam mengelola usahataninya sebagian petani masih kesulitan untuk memperoleh air pada saat dibutuhkan. Pembagian air irigasi untuk setiap Desa dilakukan secara bergilir dengan tujuan agar petani dapat memperoleh air secara adil dan merata. Pembagian air irigasi merupakan suatu kegiatan yang dilakukan untuk membagi air di bangunan bagi dalam jaringan primer dan jaringan sekunder. Giliran pembagian air dilakukan secara bergantian sesuai dengan waktu yang telah ditetapkan untuk periode 10 hari. Untuk menentukan waktu pemberian air pada setiap saluran harus diketahui terlebih dahulu debit atau persentase ketersediaan air dan luas lahan yang diairi oleh masing-masing saluran. Kemudian luas lahan pada masing-masing saluran di bagi dengan jumlah lahan keseluruhan dan dikalikan dengan periode waktu 10 hari dikali 24 jam. Selanjutnya dibuat beberapa alternatif jadwal pemberian air, dan dipilih jadwal yang terbaik yaitu jadwal dengan selang waktu pemberian airnya pendek sehingga saluran dan lahan tidak cepat kering. 


\section{Pengawasan Saluran dan Penggunaan Air Oleh Petani}

Tabel 8. Distribusi Tingkat Pelaksanaan Pengawasan Saluran Dan Penggunaan Air Oleh Petani

\begin{tabular}{|c|c|c|c|c|c|c|c|}
\hline \multirow{3}{*}{ No } & \multirow{3}{*}{ Indikator } & \multicolumn{6}{|c|}{ Kategori skor } \\
\hline & & \multicolumn{2}{|c|}{ Setuju } & \multicolumn{2}{|c|}{ Kurang Setuju } & \multicolumn{2}{|c|}{ Tidak Setuju } \\
\hline & & Frekuensi & $\%$ & Frekuensi & $\%$ & Frekuensi & $\%$ \\
\hline 1 & $\begin{array}{l}\text { Saluran irigasi dalam } \\
\text { kondisi baik }\end{array}$ & 30 & 78,9 & 8 & 21,1 & 0 & 0 \\
\hline 2 & $\begin{array}{l}\text { Tidak terjadi } \\
\text { kerusakan disebabkan } \\
\text { anggota (petani) }\end{array}$ & 32 & 84,2 & 2 & 5,3 & 4 & 10,5 \\
\hline 3 & $\begin{array}{l}\text { Anggota } \\
\text { menggunakan air } \\
\text { sesuai jadwal yang } \\
\text { ditentukan }\end{array}$ & 31 & 81,6 & 7 & 18,4 & 0 & 0 \\
\hline
\end{tabular}

Sumber: Data Primer (diolah), 2018

Berdasarkan Tabel 8 diatas dapat dilihat bahwa dari hasil jawaban responden mengenai kondisi saluran irigasi dalam keadaan yang baik yaitu dengan persentase sebesar 78,9 persen. Untuk indikator tidak terjadi kerusakan yang diakibatkan oleh petani dengan persentase 84,2 persen. Sedangkan mengenai anggota yang menggunakan air sesuai jadwal yang ditentukan dengan persentase sebesar 81,6 persen.

Tabel 9. Rata-Rata Tingkat Pelaksanaan Pengawasan Saluran dan Penggunaan Air Oleh Petani

\begin{tabular}{clcc}
\hline No & \multicolumn{1}{c}{ Indikator } & Skor & Kategori \\
\hline $\mathbf{1}$ & Saluran irigasi dalam kondisi baik & 2,79 & Setuju \\
$\mathbf{2}$ & $\begin{array}{l}\text { Tidak terjadi kerusakan disebabkan } \\
\text { anggota (petani) }\end{array}$ & 2,74 & Setuju \\
$\mathbf{3}$ & $\begin{array}{l}\text { Anggota menggunakan air sesuai } \\
\text { jadwal yang ditentukan } \\
\quad \text { Rata-rata }\end{array}$ & 2,82 & Setuju \\
& & $\mathbf{2 , 7 8}$ & Setuju \\
\hline
\end{tabular}

Sumber: Data Primer (diolah), 2018

Berdasarkan Tabel 9 diatas menjelaskan bahwa saluran irigasi dalam kondisi yang baik dengan skor 2,79 dan tidak terjadi kerusakan yang diakibatkan oleh petani dengan skor 2,74. Kemudian mengenai penggunaan air oleh petani dengan nilai skor sebesar 2,82, artinya ratarata petani menggunakan air sesuai dengan jadwal yang telah ditentukan sebelumnya. Dari hasil skor ketiga indikator tersebut dapat disimpulkan bahwa tingkat pelaksanaan pengawasan saluran dan penggunaan air oleh petani sangat baik dengan rata-rata skor 2,78. Jika terdapat petani yang melakukan pencurian air maka akan dikenakan sanksi oleh pengurus keujreun blang yaitu membayar denda sebesar 50\% dari iuran wajib. Petani juga tidak diperbolehkan mengambil air dari saluran primer dan sekunder walaupun saluran tersebut dekat dengan lahan persawahan. 


\section{Penegakan Adat Blang}

Tabel 10. Distribusi Tingkat Pelaksanaan Penegakan Adat Blang

\begin{tabular}{|c|c|c|c|c|c|c|c|}
\hline \multirow{3}{*}{ No } & \multirow{3}{*}{ Indikator } & \multicolumn{6}{|c|}{ Kategori skor } \\
\hline & & \multicolumn{2}{|l|}{ Selalu } & \multicolumn{2}{|c|}{ Kadang-kadang } & \multicolumn{2}{|c|}{ Tidak Pernah } \\
\hline & & Frekuensi & $\%$ & Frekuensi & $\%$ & Frekuensi & $\%$ \\
\hline 1 & Keikutsertaan & 13 & 34,2 & 9 & 23,7 & 16 & 42,1 \\
\hline & $\begin{array}{l}\text { dalam kegiatan } \\
\text { gotong royong }\end{array}$ & & & & & & \\
\hline 2 & Keikutsertaan & 34 & 89,5 & 4 & 10,5 & 0 & 0 \\
\hline & $\begin{array}{l}\text { dalam kegiatan } \\
\text { kheunduri blang }\end{array}$ & & & & & & \\
\hline 3 & $\begin{array}{l}\text { Pembayaran iuran } \\
\text { sesuai waktu yang } \\
\text { ditetapkan }\end{array}$ & 32 & 84,2 & 6 & 15,8 & 0 & 0 \\
\hline
\end{tabular}

Berdasarkan Tabel 10 diatas dapat dilihat bahwa keikutsertaan petani dalam kegiatan gotong royong untuk membersihkan saluran irigasi hanya dengan persentase sebesar 34,2 persen petani yang selalu ikut serta dalam kegiatan tersebut. Sedangkan 42,1 persen petani lainnya tidak pernah ikut dalam kegiatan gotong royong. Bagi petani yang tidak ikut dalam gotong royong harus membayarkan uang kepada keujreun blang sebagai gantinya. Kemudian sebesar 89,5 persen petani selalu ikut serta dalam kegiatan kheunduri blang dan hanya 10,5 persen petani yang kadang-kadang ikut dalam kegiatan tersebut. Dalam kegiatan kheunduri blang semua petani yang ikut serta berkumpul disatu tempat dengan membawa masakan dari rumah masing-masing, dalam kegiatan ini dilakukan doa bersama yang di pimpin oleh tengku imum gampong. Setelah berdoa selesai baru dilanjutka dengan makan bersama. Mengenai pembayaran iuran sesuai waktu yang telah ditentukan, 84,2 persen petani membayarkan iuran kepada keujreun blang sesuai waktu yang telah ditentukan.

Tabel 11. Rata-Rata Tingkat Pelaksanaan Penegakan Adat Blang

\begin{tabular}{clcc}
\hline No & \multicolumn{1}{c}{ Indikator } & Skor & Kategori \\
\hline $\mathbf{1}$ & $\begin{array}{l}\text { Keikutsertaan dalam kegiatan } \\
\text { gotong royong }\end{array}$ & 1,92 & Kadang-kadang \\
$\mathbf{2}$ & $\begin{array}{l}\text { Keikutsertaan dalam kegiatan } \\
\text { kheunduri blang }\end{array}$ & 2,89 & Selalu \\
$\mathbf{3}$ & $\begin{array}{l}\text { Pembayaran iuran sesuai } \\
\text { waktu yang ditetapkan }\end{array}$ & 2,84 & Selalu \\
& Rata-rata & $\mathbf{2 , 5 5}$ & Selalu \\
\hline
\end{tabular}

Sumber: Data Primer (diolah), 2018

Berdasarkan Tabel 11 diatas memperlihatkan bahwa keikutsertaan petani dalam kegiatan gotong royong dengan nilai skor sebesar 1,92, artinya tingkat partisipasi petani dalam kegiatan gotong royong masih tergolong sedang. Kemudian untuk keikutsertaan petani dalam kegiatan kheunduri blang dengan nilai skor 2,89, artinya tingkat partisipasi petani dalam kegiatan adat 
ini masih sangat tinggi. Pembayaran iuran sesuai waktu yang ditetapkan dengan nilai skor sebesar 2,84 menunjukkan bahwa hampir semua petani membayar iuran dan sesuai dengan waktu yang telah ditentukan. Biasanya batas waktu yang ditentukan untuk membayar iuran selambat-lambatnya satu bulan setelah masa panen. Iuran wajib dapat berupa uang atau gabah kering sebesar $50 \mathrm{Kg} / \mathrm{Ha} /$ musim tanam yang diserahkan kepada pengurus keujreun blang. Hasil iuran yang telah dibayarkan tidak semuanya digunakan sebagai imbalan pengurus keujreun blang namun pengurus hanya mendapatkan 60 persen dari jumlah iuran, selebihnya digunakan untuk biaya pemeliharaan jaringan irigasi, biaya administrasi dan dana sosial. Dari hasil ratarata skor ketiga indikator diatas dapat disimpulkan bahwa tingkat pelaksanaan penegakan adat blang sudah baik yaitu sebesar 2,55.

\section{Penyelesaian Sengketa}

Tabel 12. Distribusi Tingkat Pelaksanaan Penyelesaian Sengketa

\begin{tabular}{|c|c|c|c|c|c|c|c|}
\hline \multirow{3}{*}{ No } & \multirow{3}{*}{ Indikator } & \multicolumn{6}{|c|}{ Kategori skor } \\
\hline & & \multicolumn{2}{|c|}{ Selalu } & \multicolumn{2}{|c|}{ Kadang-kadang } & \multicolumn{2}{|c|}{ Tidak Pernah } \\
\hline & & Frekuensi & $\%$ & Frekuensi & $\%$ & Frekuensi & $\%$ \\
\hline 1 & $\begin{array}{l}\text { Konflik diselesaikan } \\
\text { oleh keujreun blang }\end{array}$ & 8 & 21,1 & 30 & 78,9 & 0 & $\mathbf{0}$ \\
\hline 2 & $\begin{array}{l}\text { Konflik diselesaikan } \\
\text { secara duek pakat }\end{array}$ & 5 & 13,2 & 30 & 78,9 & 3 & 7,9 \\
\hline 3 & $\begin{array}{l}\text { Tindakan lanjutan } \\
\text { terhadap pelanggaran }\end{array}$ & 2 & 5,3 & 31 & 81,5 & 5 & 13,2 \\
\hline
\end{tabular}

Berdasarkan Tabel 12 diatas menjelaskan bahwa tingkat penyelesaian konflik atau sengketa tidak selalu diselesaikan oleh keujreun blang, hal ini terlihat pada tabel hanya sebesar 21,1 persen konflik diselesaikan oleh lembaga adat keujreun blang. Sama halnya dengan proses penyelesaian sengketa yaitu sebesar 78,9 persen penyelesaian sengketa tidak selalu diselesaikan secara duek pakat atau musyawarah tetapi hanya antar petani yang berselisih dengan keujreun blang sebagai penengah atau penasehat. Mengenai tindakan lanjutan terhadap pelanggaran yang dilakukan oleh petani yaitu sebesar 81,5 persen hanya kadang-kadang dilakukan, artinya tidak semua pelanggaran yang terjadi di tindaklanjuti.

Tabel 13. Rata-Rata Tingkat Pelaksanaan Penyelesaian Sengketa

\begin{tabular}{clcc}
\hline No & \multicolumn{1}{c}{ Indikator } & Skor & Kategori \\
\hline 1 & $\begin{array}{l}\text { Penyelesaian konflik oleh keujreun } \\
\text { blang }\end{array}$ & 2,21 & Kadang-kadang \\
2 & $\begin{array}{l}\text { Penyelesaian konflik secara duek } \\
\text { pakat }\end{array}$ & 2,05 & Kadang-kadang \\
Tindakan lanjutan terhadap \\
pelanggaran \\
Rata-rata
\end{tabular}

Sumber: Data Primer (diolah), 2018

Berdasarkan Tabel 13 diatas menunjukkan bahwa rata-rata tingkat pelaksanaan penyelesaian sengketa adalah sebesar 2,06, dapat dikatakan bahwa tingkat penyelesaian sengketa tersebut masih tergolong sedang atau belum cukup baik. Hal tersebut dapat dilihat dari indikator penyelesaian konflik oleh keujreun blang dengan nilai skor 2,21, penyelesaian konflik 
secara duek pakat dengan nilai skor 2,05 dan tindakan lanjutan terhadap pelanggaran dengan nilai skor 1,92 .

\section{Pemberian Teguran dan Sanksi}

Tabel 14. Distribusi Tingkat Pelaksanaan Pemberian Teguran dan Sanksi

\begin{tabular}{|c|c|c|c|c|c|c|c|}
\hline \multirow{3}{*}{ No } & \multirow{3}{*}{ Indikator } & \multicolumn{6}{|c|}{ Kategori skor } \\
\hline & & \multicolumn{2}{|l|}{ Sesuai } & \multicolumn{2}{|c|}{ Kurang Sesuai } & \multicolumn{2}{|c|}{ Tidak Sesuai } \\
\hline & & Frekuensi & $\%$ & Frekuensi & $\%$ & Frekuensi & $\%$ \\
\hline 1 & $\begin{array}{l}\text { Pemberian sanksi } \\
\text { terhadap pelanggar } \\
\text { aturan tata tanam }\end{array}$ & 38 & 100 & $\mathbf{0}$ & $\mathbf{0}$ & $\mathbf{0}$ & $\mathbf{0}$ \\
\hline 2 & $\begin{array}{l}\text { Pemberian sanksi } \\
\text { terhadap } \\
\text { keterlambatan } \\
\text { pembayaran iuran }\end{array}$ & 33 & 86,8 & 5 & 13,2 & $\mathbf{0}$ & $\mathbf{0}$ \\
\hline 3 & $\begin{array}{l}\text { Pemberian sanksi } \\
\text { terhadap pencurian } \\
\text { air }\end{array}$ & 24 & 63,2 & 10 & 26,3 & 4 & 10,5 \\
\hline
\end{tabular}
Sumber: Data Primer (diolah), 2018

Berdasarkan Tabel 14 diatas menunjukkan bahwa pemberian sanksi terhadap pelanggar aturan tata tanam yang dilakukan oleh keujreun blang sudah sesuai dengan aturan yang ditetapkan yaitu sebesar 100 persen, dalam hal ini sanksi yang diberikan adalah pelayanan pembagian air diluar tanggungan keujreun blang. Mengenai pemberian sanksi terhadap keterlambatan pembayaran iuran sudah sesuai dengan aturan yaitu dengan persentase sebesar 86,8 persen. Bagi anggota yang menunggak membayar iuran wajib akan dikenakan denda sebesar 100 persen dari jumlah tunggakan. Kemudian mengenai indikator pemberian petani terhadap pencurian air juga sesuai dengan aturan yang ditetapkan yaitu dengan persentase 63,2 persen. Bagi anggota yang terbukti melakukan pencurian air maka akan diberikan sanksi sebesar 50 persen dari jumlah iuran wajib.

Tabel 15. Rata-Rata Tingkat Pelaksanaan Pemberian Teguran dan Sanksi

\begin{tabular}{clcc}
\hline No & \multicolumn{1}{c}{ Indikator } & Skor & Kategori \\
\hline 1 & $\begin{array}{l}\text { Pemberian sanksi terhadap pelanggar } \\
\text { aturan tata tanam }\end{array}$ & 3 & Sesuai \\
2 & $\begin{array}{l}\text { Pemberian sanksi terhadap keterlambatan } \\
\text { pembayaran iuran }\end{array}$ & 2,87 & Sesuai \\
3 & $\begin{array}{l}\text { Pemberian sanksi terhadap pencurian air } \\
\text { Rata-rata }\end{array}$ & 2,53 & $\begin{array}{l}\text { Sesuai } \\
\text { Sesuai }\end{array}$ \\
\hline
\end{tabular}

Sumber: Data Primer (diolah), 2018

Pada tabel 15 diatas menunjukkan bahwa rata-rata tingkat pelaksanaan pemberian teguran dan sanksi sudah sesuai dengan aturan pelanggaran dan sanksi yang telah ditetapkan yaitu dengan rata-rata 2,80. Hal tersebut berdasarkan pemberian sanksi terhadap pelanggar aturan tata tanam dengan nilai skor 3, pemberian sanksi terhadap keterlambatan pembayaran iuran dengan nilai skor 2,87 dan pemberian sanksi terhadap anggota yang melakukan tindakan pencurian air dengan nilai skor sebesar 2,55. Dapat disimpulkan bahwa tingkat pelaksanaan pemberian teguran dan sanksi tergolong sudah baik. 


\section{Tingkat Efektivitas Fungsi Lembaga Adat Keujreun Blang dalam Pengelolaan Air Irigasi}

Pada dasarnya efektifitas fungsi dari suatu lembaga atau organisasi tidak terlepas dari pelaksanaan fungsi, dan orang-orang yang terlibat didalamnya. Koordinasi yang baik antara orang-orang yang telibat didalamnya mampu menciptakan keadaan yang kondusif dalam menjalankan fungsinya. Dalam hal ini pelaksanaan fungsi dari lembaga adat keujreun blang yang dijalankan harus sesuai dengan peraturan yang telah ditetapkan, karena hal tersebut merupakan suatu pedoman untuk mencapai tujuan yang diinginkan. Semakin sesuai pelaksanaan fungsi dengan peraturan yang telah ditetapkan, maka akan semakin efektif fungsi lembaga adat keujreun blang tersebut.

Tabel 16. Pelaksanaan Fungsi Lembaga Adat Keujreun Blang Dalam Pengelolaan Air Irigasi

\begin{tabular}{cccc}
\hline No & Kriteria Efektif & Jumlah Sampel & Persentase (\%) \\
\hline 1 & Efektif & 36 & 94,7 \\
2 & Kurang efektif & 2 & 5,3 \\
3 & Tidak efektif & 0 & 0 \\
\hline Sumber: Data Primer (diolah), 2018 & &
\end{tabular}

Pada Tabel 16 dapat kita ketahui bahwa secara keseluruhan pelaksanaan fungsi keujreun blang dalam pengelolaan air irigasi di Kecamatan Kuta Cot Glie tergolong efektif dengan persentase sebesar 94,7 persen dengan jumlah 36 petani. Keefektifan ini berasal dari pengawasan adat blang yang sudah baik, pengawasan ketersediaan air, pengawasan saluran dan penggunaan air oleh petani, penegakan adat blang, serta pemberian teguran dan sanksi. Kurang efektifnya pelaksanaan fungsi terdapat pada pelaksanaan penyelesaian sengketa yang masih tergolong kurang baik. Dengan demikian hipotesis awal yang menyatakan bahwa fungsi lembaga adat keujreun blang dalam pengelolaan air irigasi di Kecamatan Kuta Cot Glie yang dinilai kurang efektif ditolak.

\section{KESIMPULAN DAN SARAN}

Berdasarkan Hasil dan pembahasan dari penelitian ini menunjukkkan bahwa secara keseluruhan pelaksanaan fungsi lembaga adat keujreun blang dalam pengelolaan air irigasi di Kecamatan Kuta Cot Glie Kabupaten Aceh Besar yang dilihat dari tingkat pelaksanaan pengawasan adat blang, pengawasan ketersediaan air, pengawasan saluran dan penggunaan air, penegakan adat blang, penyelesaian sengketa, dan pemberian teguran dan sanksi dinilai efektif yaitu sebesar 94,7 persen dengan jumlah 36 petani. Adapun saran dari hasil penelitian ini yaitu bagi pihak pengurus lembaga adat keujreun blang dan petani untuk terus saling bekerjasama guna meningkatkan kinerja dari keujreun blang dalam menjalankan fungsinya dalam pengelolaan air irigasi agar pencapaian fungsi dari keujreun blang tersebut dapat berjalan lebih maksimal. Sebagaimana diketahui bahwa air merupakan hal yang paling penting dalam usaha pertanian guna untuk meningkatkan hasil produksi dan pendapatan para petani.

\section{DAFTAR PUSTAKA}

Ansori A., Ariyanto A., dan Syahroni. 2013. Kajian Efektivitas dan Efisiensi Jaringan Irigasi Terhadap Kebutuhan Air pada Tanaman Padi (Studi Kasus Irigasi Kaiti Samo Kecamatan Rambah Kabupaten Rokan Hulu). Fakultas Teknik Universitas Pasir Pengaraian, Riau. 
Bakar A., Yusoef A., dan Anwar. 2012. Peran Lembaga Adat Keujreun Blang dalam Peningkatan Kesejahteraan Petani Sawah Di Kabupaten Bireun. Jurnal Pendidikan dan Pembinaan Ummat. 1: 13-14 (6).

Hakim, A, R. 2017. Eksistensi Keujreun Blang dalam Pengelolaan Air Irigasi Persawahan di Gampong Blang Pateuk Kecamatan Seunagan Kabupaten Nagan Raya. Skripsi. Fakultas Ilmu Sosial dan Politik Universitas Syiah Kuala, Banda Aceh.

Jannata, Abdullah, dan Priyati. 2015. Analisa Kinerja Pengelolaan Irigasi di Daerah Irigasi Lemor Kabupaten Lombok Timur Nusa Tenggrara Barat. Jurnal Ilmiah Rekayasa Pertanian Dan Biosistem. 3: 113 (1).

Juned, H, T. 2008. Peran Keujreun Blang dalam Memajukan Pertanian dan Meugoe. Dalam Andri Kiawan, 2016. Kedudukan dan Fungsi Keujreun Blang dalam Pengelolaan Pertanian di Kecamatan Darussalam Kabupaten Aceh Besar. Skripsi. Fakultas Hukum Universitas Syiah Kuala, Banda Aceh.

Kiawan, A. 2016. Kedudukan dan Fungsi Keujreun Blang Dalam Pengelolaan Pertanian di Kecamatan Darussalam Kabupaten Aceh Besar. Skripsi. Fakultas Hukum Universitas Syiah Kuala, Banda Aceh.

Kurniawan, A. 2005. Transformasi Pelayanan Publik. Yogyakarta.

Lubis, S.B., Hari, dan Martani, H. 2009. Pengantar Teori Organisasi: Suatu Pendekatan Makro. Jakarta.

Maifianti, K., Suci. 2014. Perspektif Komunikasi Ritual Kanuri Blang Sebagai Bentuk Kerjasama dalam Masyarakat Tani di Kecamatan Samatiga Kabupaten Aceh Barat Provinsi Aceh. Sekolah Pascasarjana Institut Pertanian Bogor, Bogor.

Mutiya, A, A. 2016. Peranan Lembaga Adat dalam Melestarikan Nilai-Nilai Piil Pesenggiri di Desa Gunung Batin Udik Kecamatan Terusan Nunyai Kabupaten Lampung Tengah. Skripsi. Fakultas Keguruan dan Ilmu Pendidikan. Universitas Lampung.

Mislini. 2006. Analisis Jaringan Komunikasi Pada Kelompok Swadaya Masyarakat. Kasus KSM di Desa Tanaman Sari Kabupaten Bogor Provinsi Jawa Barat. Tesis. Program Studi Ilmu Penyuluhan pembangunan Institut pertanian Bogor. Bogor.

Nasdian, T. 2003. Pengembangan Masyarakat (Community Development) dalam Hendra 2013. Totua Ngata dan Konflik Studi Atas Posisi Totuo Ngata Sebagai Lembaga Adat di Kecamatan Marawola. Jurnal Antropologi Indonesia. 34: 17 (1).

Nazir, Moh. 2003. Metode Penelitian. Ghalia Indonesia, Jakarta 
Peraturan Gubernur Aceh No. 45 Tahun 2015 Tentang Peran Keujreun Blang dalam Pengelolaan Irigasi.

Peraturan Pemerintah Nomor. 23 Tahun 1982 Tentang Irigasi.

Rahman, Abd Said. 2013. Efektivitas Organisasi Kecamatan Sebagai Satuan Kerja Perangkat Daerah. Jurnal Ilmu Politik dan Pemerintahan Lokal. 2: 203 (1).

Syahputra, Hariadi, dan Subejo. 2016. Peran Keujreun Blang Terhadap Perilaku Petani dalam Pengelolaan Air Pertanian di Nanggroe Aceh Darussalam. Skripsi. Program Studi Penyuluhan dan Komunikasi Pembangunan. Universitas Gadjah Mada, Yogyakarta.

Sahrirudin, Permana, dan Farida. 2014. Analisis Kebutuhan Air Irigasi Untuk Daerah Irigasi Cimanuk Kabupaten Garut. Jurnal Irigasi. 13: 2 (1).

Wilsa, Nurdin M. 2016. Efektivitas Fungsi Lembaga Adat Aceh dalam Penyelesaian Tindak Pidana Ringan di Tingkat Gampong. Jurnal Ilmiah Dunia Ilmu. 2: 161 (3).

Yusoef A., Abubakar, dan Yanis R. 2011. Konsep Pemanfaatan Lembaga Adat Keujreun Blang dalam Meningkatkan Kesejahteraan Petani Pemakai Air (Sawah) di Kabupaten Bireun. Laporan Hasil Penelitian di Biayai Oleh Dikti. Universitas Serambi Mekah. Aceh.

Yulia, Sulaiman, dan Herinawati. 2012. Pemberdayaan Fungsi dan Wewenang Keujreun Blang di Kecamatan Swang Aceh Utara (dalam Pelaksanaan Qanun Nomor 10 Tahun 2008 Tentang Lembaga Adat). Jurnal Dinamika Hukum. 12: 369 (2). 